Elik Vatashsky MD, Yuval Haskel MD, Benzion Beilin MD, H.B. Aronson MB CH B DA FFARCS(1)

\title{
Common bile duct pressure in dogs after opiate injection - epidural versus intravenous route
}

The effect on the common bile duct pressure of epidurally injected morphine and fentanyl, was compared with that of intravenous injections of the same drugs in 12 mongrel dogs. Intravenous injection of morphine $\left(0.1 \mathrm{mg} \cdot \mathrm{kg}^{-1}\right)$ or fentanyl $\left(0.01 \mathrm{mg} \cdot \mathrm{kg}^{-1}\right)$ significantly elevated the common bile duct pressure from $10.48 \pm 0.37$ to $21.68 \pm$ $0.33 \mathrm{~cm} \mathrm{H}_{2} \mathrm{O}$ and from $9.66 \pm 0.331014 .14 \pm 0.21 \mathrm{~cm}$ $\mathrm{H}_{2} \mathrm{O}$ respectively. These increases occurred within 4-15 minutes after injection and lasted for about 2-3 hours. When the narcotics in identical dosages were injected epidurally, the common bile duct pressures were unchanged during the four hours of investigation.

Further studies are planned to determine whether this beneficial effect of epidural narcotics applies also in the human clinical situation.

\section{Key words}

ANALGESICS: morphine, fentanyl; ANALGESIA POSTOPERATIVE: epidural; COMMON BILE DUCT; pressure.
Epidural injection of opiate drugs is widely used in clinical practice after surgery, following the encouraging reports of their effectiveness. ${ }^{1-4}$ However, undesirable side-effects such as respiratory depression, pruritis and urinary retention are disadvantages. ${ }^{4-7}$ When used either subcutaneously, intramuscularly or intravenously, therapeutic doses of opiates can also cause marked pressure increases in the biliary tract, resulting in epigastric distress or typical biliary colic. ${ }^{8-12}$

It was recently reported that when injected by the epidural route after cholecystectomy, narcotics have produced satisfactory postoperative analgesia. ${ }^{4,13}$ Since the effect of epidurally injected opiate drugs on the common bile duct pressure has not as yet been reported, we thought it important to study this question in animals. This study reports the effect of equipotent doses of morphine and fentanyl given by either epidural or intravenous injection on the common bile duct pressure in dogs.

\section{Methods}

Twelve fully-grown mongrel dogs of both sexes (weighing 18-25 kg) were brought to the laboratory after a 12-hour fast and allowed to accommodate to their surroundings for a one-hour period. An indwelling catheter was then placed in a peripheral fore-leg vein and anaesthesia induced with thiopentone (30 $\mathrm{mg} \cdot \mathrm{kg}^{-1}$ ) IV

A midline laparotomy was performed and the extrahepatic biliary tract identified. A polyethylene catheter (1.4 mm ID) was introduced through the fundus of the gall bladder into the common bile duct via the cystic duct. A purse string was tied around the catheter at the fundus of the gall bladder and on the cystic duct in order to prevent any leakage on movement of the tip of the catheter. Placement of a 
17 gauge Touhy needle in the lumbar epidural space was accomplished using the "loss of resistance" technique, ${ }^{14}$ and an epidural catheter was inserted. All catheters were exteriorized subcutaneously and secured. Accurate epidural catheter placement was confirmed when almost immediate hindlimb (leg limb) paralysis occurred after the injection of $2 \mathrm{ml}$ of 0.5 per cent bupivacaine. The common bile duct catheter was filled with saline and closed. The dogs were then allowed to recover from the anaesthesia and paresis of the hind limbs, given antibiotic cover and returned to the animal quarters. Twenty-four to forty-eight hours later, the dogs were again brought to the laboratory after a 12-hour fast, and anaesthetised with a sleep dose of IV thiopentone (15 $\mathrm{mg} \cdot \mathrm{kg}^{-1}$ ). Anaesthesia was maintained with thiopentone $3 \mathrm{mg} \cdot \mathrm{kg}^{-1} \cdot \mathrm{hr}^{-1}$. The animals lay on their backs and the distal end of the common bile duct catheter was perfused with saline using an infusion pump (Harvard model 933) at a rate of $1 \mathrm{ml}$ per minute. Intraluminal pressure was transmitted through the saline-filled catheter and recorded in $\mathrm{cm}$ $\mathrm{H}_{2} \mathrm{O}$ on a VR-6 Simultrace Recorder (Electronics for Medicine, Inc.). The table was tilted $15^{\circ}$ in the head-up position to avoid cephalad spread of the narcotics when injected epidurally. The zero point of the recorder was adjusted to the level of the common bile duct (mid-axillary line) and maintained there for the entire set of measurements.

After the common bile duct pressure stabilized for 20-30 minutes (control), the study was commenced. Each dog then acted as its own control for both drugs, which were injected by two different routes, inravenously and epidurally, with an interval of one to two days between injections.

The dogs were divided into two groups: Group I received morphine $0.1 \mathrm{mg} \cdot \mathrm{kg}^{-1}$ while Group II received fentanyl $0.01 \mathrm{mg} \cdot \mathrm{kg}^{-1}$. Epidural injectons of these drugs were made on the second or third days of the study, and the IV injections one to two days subsequently. Pressures in the common bile duct for the first half hour were measured every two minutes after completion of each narcotic injection, and again every five minutes during the following four hours.

Pulse and respiratory rates were checked every five minutes and blood samples from the femoral artery were taken every 30 minutes for blood gas analysis. At the end of the four-hour study period $2 \mathrm{ml}$ of 0.5 per cent bupivacaine was injected through the epidural catheter to reconfirm correct placement

Statistical analysis of the results was done using the multiple t-test proposed by Wallenstein et al. ${ }^{15}$ for multiple re-testing of the difference between two means. Results are presented as mean values and SEM. Statistically, significant differences are indicated only when $p$ values are 0.001 or less.

\section{Results}

The pressures in the common bile ducts before injection of the narcotics (either epidurally or intravenously), were not significantly different in the two groups (Table). Intravenous injection of either narcotic elevated the common bile duct pressure (Table) but there were differences in peak effect, plateau and the return to the control levels. Thus, in Group I, after IV morphine, the common bile duct pressure started to increase after $6 \pm 2 \mathrm{~min}$ (mean \pm SEM). The peak pressure was reached at $12 \pm 3 \mathrm{~min}$, remained there until $111 \pm 12 \mathrm{~min}$, and returned to control levels after $136 \pm 6 \mathrm{~min}$.

In Group II, when fentanyl was injected intravenously, the common bile duct pressure started to increase after $4 \pm 1 \mathrm{~min}$, peak pressure was reached at $9 \pm 3 \mathrm{~min}$, the plateau continued until $37 \pm 6 \mathrm{~min}$ and the pressure returned to the control level after $47 \pm 8 \mathrm{~min}$. In both groups, when narcotics were injected through the epidural catheter, the pressure in the common bile duct did not change from the control values in any of the dogs during the four hours of observation. During the same period of observation respiratory and pulse rates and blood gases did not significantly change after either epidural or intravenous injection of the two narcotics.

\section{Discussion}

Postoperative pain is commonly treated by epidural injection of opiates given in varying dose schedules. To our knowledge, the effect of epidurally injected opiates on the common bile duct pressure has not been studied, in spite of the wide clinical use of this method of postoperative analgesia, after abdominal surgery including extrahepatic operations. The results of this study indicate that within 4-15 minutes of the intravenous injection of either morphine or fentanyl in dogs, common bile duct pressures were significantly raised above their control values, a finding that is in keeping with 
TABLE Common bile duct pressure $\left(\mathrm{cmH}_{2} \mathrm{O}\right)$ afler narcotic injection (mean $\pm \mathrm{SEM}$ )

\begin{tabular}{|c|c|c|c|c|c|c|c|c|c|c|c|c|c|}
\hline \multirow{2}{*}{$\begin{array}{l}\text { Drug } \\
\text { injected }\end{array}$} & \multirow{2}{*}{$\begin{array}{l}\text { Roule of } \\
\text { injection }\end{array}$} & \multirow[b]{2}{*}{ Contrul } & \multicolumn{11}{|c|}{ Time After Injection (minutes) } \\
\hline & & & 4 & 6 & 10 & 20 & 40 & 60 & 80 & 100 & 120 & 140 & 160 \\
\hline \multicolumn{14}{|l|}{ Group I } \\
\hline $\begin{array}{c}\text { Morphine } \\
\qquad n=6\end{array}$ & IV & $\begin{array}{r}10.48 \\
\pm 0.37\end{array}$ & $\begin{array}{r}11.50 \\
\pm 0.42\end{array}$ & $\begin{array}{r}11.83 \\
\pm 0.47\end{array}$ & $\begin{array}{l}21.66 \\
\pm 0.33 \\
*\end{array}$ & $\begin{array}{r}21.68 \\
\pm 0.33 \\
*\end{array}$ & $\begin{aligned} & 21.50 \\
& \pm 0.22 \\
& *\end{aligned}$ & $\begin{array}{l}21.66 \\
\pm 0.34 \\
*\end{array}$ & $\begin{array}{l}21.63 \\
\pm 0.31 \\
*\end{array}$ & $\begin{array}{l}21.64 \\
\pm 0.33 \\
*\end{array}$ & $\begin{array}{l}20.83 \\
\pm 0.30 \\
*\end{array}$ & $\begin{array}{r}14.83 \\
\pm 0.70 \\
*\end{array}$ & $\begin{array}{r}10.33 \\
\pm 0.42\end{array}$ \\
\hline $\begin{array}{c}\text { Morphine } \\
\qquad n=6\end{array}$ & Epidural & $\begin{array}{r}10.33 \\
\pm 0.42\end{array}$ & $\begin{array}{r}10.37 \\
\pm 0.42\end{array}$ & $\begin{array}{r}10.66 \\
\pm 0.42\end{array}$ & $\begin{array}{r}10.34 \\
\pm 0.41\end{array}$ & $\begin{array}{r}10.16 \\
\pm 0.33\end{array}$ & $\begin{array}{r}10.64 \\
\pm 0.33\end{array}$ & $\begin{array}{r}9.97 \\
\pm 0.48\end{array}$ & $\begin{array}{r}10.08 \\
\pm 0.36\end{array}$ & $\begin{array}{r}10.54 \\
\pm 0.41\end{array}$ & $\begin{array}{r}10.26 \\
\pm 0.38\end{array}$ & $\begin{array}{r}10.31 \\
\pm 0.40\end{array}$ & $\begin{array}{r}10.42 \\
\pm 0.48\end{array}$ \\
\hline \multicolumn{14}{|l|}{ Group II } \\
\hline $\begin{array}{c}\text { Fentanyl } \\
n=6\end{array}$ & IV & $\begin{array}{c}9.66 \\
\pm 0.33\end{array}$ & $\begin{array}{r}13.16 \\
\pm 0.20\end{array}$ & $\begin{array}{l}13.83 \\
\pm 0.20 \\
*\end{array}$ & $\begin{array}{l}14.33 \\
\pm 0.21 \\
*\end{array}$ & $\begin{array}{l}14.16 \\
\pm 0.30 \\
*\end{array}$ & $\begin{array}{r}12.66 \\
\pm 0.66\end{array}$ & $\begin{array}{r}10.66 \\
\pm 0.49\end{array}$ & $\begin{array}{r}10.16 \\
\pm 0.47\end{array}$ & $\begin{array}{r}10.06 \\
\pm 0.18\end{array}$ & $\begin{array}{r}10.12 \\
\pm 0.48\end{array}$ & $\begin{array}{r}9.92 \\
\pm 0.38\end{array}$ & $\begin{array}{r}9.80 \\
+0.42\end{array}$ \\
\hline $\begin{array}{c}\text { Fentanyl } \\
n=6\end{array}$ & Epidural & $\begin{array}{r}9.26 \\
\pm 0.37\end{array}$ & $\begin{array}{r}9.28 \\
\pm 0.37\end{array}$ & $\begin{array}{r}9.26 \\
\pm 0.37\end{array}$ & $\begin{array}{r}9.34 \\
\pm 0.35\end{array}$ & $\begin{array}{r}9.32 \\
\pm 0.34\end{array}$ & $\begin{array}{r}9.31 \\
\pm 0.34\end{array}$ & $\begin{array}{r}10.16 \\
\pm 0.36\end{array}$ & $\begin{array}{r}10.08 \\
\pm 0.47\end{array}$ & $\begin{array}{r}10.21 \\
\pm 0.38\end{array}$ & $\begin{array}{r}9.47 \\
\pm 0.56\end{array}$ & $\begin{array}{r}9.68 \\
\pm 0.43\end{array}$ & $\begin{array}{r}9.54 \\
\pm 0.51\end{array}$ \\
\hline
\end{tabular}

* Significant difference at $\mathrm{p}<0.001$ level.

previous studies. ${ }^{8-10.12}$ However, epidural injection of the same opiates in identical dosage, did not increase pressure in the canine common bile duct. The reason for this difference in the effect on the bile duct pressure when opiates are given by the epidural route as opposed to intravenous injection is not clear. Recently it was shown ${ }^{16}$ that when morphine was used epidurally, the CSF concentrations of the drug after one hour were 45-100 times higher than in the plasma at the corresponding time. At three and five hours, the CSF concentrations exceeded the plasma values by $100-250$ and $125-$ 175 times respectively. This high concentration of the drug in the CSF provides significant amounts of narcotic at the receptor level at the dorsal hom in the spinal cord and could account for the long duration of analgesia. ${ }^{17}$

The genesis of basal motor activity of the sphincter of Oddi is myogenic and is regualted by two opposing neural pathways - one excitatory and the other inhibitory - both of which contain different intramural opiate receptors. ${ }^{18}$

We can only speculate that when narcotics are injected epidurally they provide relaxation of the sphincter of Oddi by stimulating mainly its inhibitory opiate receptors. It is obvious that one cannot extrapolate results of this animal study to the clinical situation. Nevertheless, the fact that the dogs' extrahepatic system is very similar anatomically, histologically and functionally to that of humans ${ }^{19,20}$ encourages us to plan similar human studies in the future.

In conclusion, small doses of morphine and fentanyl given epidurally did not increase the common bile duct pressure in dogs during the four hours following injection.

\section{References}

1 Behar M, Magora F, Olshwang D, Davidson JT. Epidural morphine in treatment of pain. Lancet 1979; 1: 527.

2 Braham $J$, King $R, M c C$ ughey W. Postoperative pain relief using epidural morphine. Anaesthesia 1980; 35: 158.

3 Wang $S K$, Nauss LA, Thomas EJ. Pain relief by intrathecally applied morphine in man. Anesthesiology 1979; 50: 149.

4 Bromage PR, Camparesi E, Chestnut D. Epidural narcotics for postoperative analgesia. Anesth Analg 1980; 59: 473.

5 Magora F, Olshwang D. Eimerl D et al. Observations on extradural morphine analgesia in various pain conditions. Br J Anaesth 1980; 52; 247.

6 Knill RL, Clement JL. Thompson WR. Epidural morphine causes delayed and prolonged ventilatory depression. Can Anaesth Soc J 1981; 28: 537.

7 Reiz S, Westberg $M$. Side effects of epidural morphine. Lancet 1980; 1: 203. 
8 Gilman A, Goodman LS, Gilman AT. The Pharmacological basis of Therapeutics, 6th Edition, New York, MacMillan Publishing Co., 1980, pp. 504.

9 Ingram $D M$, Cachpole $B N$. Effects of opiates on gastroduodenal motility following surgical operation. Digestive Diseases and Sciences 1981; 26: 289.

10 Jones RM, Detner $M$, Hill $A B$, Bjoraker $D G$, $P a n d i t U$. Incidence of choledochoduodenal sphincter spasm during fentanyl-supplemented anesthesia. Anesth Analg 1981; 60: 638.

11 Radnay $P A$, Brodman E, Markiker D, Duncalf $D$. The effect of equi-analgesic doses of fentanyl, morphine, meperedine and pentazocaine on common bile duct pressure. Anaesthetist 1980; 29: 26.

12 Economou G, Ward-McQuaid JNA. A cross-over comparison of the effect of morphine, pethidine, pentozocaine and phenozocaine on biliary pressure. Gut 1971; 12: 218.

13 Anderson I, Thompson WR, Varkey GP, Knill RL. Lumbar epidural morphine as an effective analgesia following cholecystectomy. Can Anaesth Soc J 1982; 28: 523.

14 Lumb L, Jones EW. Veterinary Anesthesia, Lea \& Feibiger, New York, 1973, pp 419.

15 Wallenstein S, Zucker CL, Fleiss JL. Some statistical methods useful in circulation research. Circ Res 1980; 47: 1

16 Nordberg G, Hedner T, Mellstrand T, Dahlstrom $B$. Pharmacokinetic aspects of epidural morphine analgesia. Anesthesiology 1983; 58: 545.

17 Kitahata $L M$, Collins JG. Spinal action of narcotic analgesia. Anesthesiology 1981; 54: 153.

18 Behar J, Bniaconi P. Neural control of the sphincter of Oddi. Physiologic role of enkephalins on the regulation of basal sphincter of Oddi motor activity in the cat. Gastroenterology 1984; 86: 134.

19 Ogawa T, Jefferson NC, Nechles HJ. Comparative study of bile drainage in dog and man. Am $\mathrm{J}$ Surg 1960; 99: 57.

20 Tanzy MF, Innes D, Martin JS, Kendall FM. A functional description of the canine choledochoduodenal flutter valve. Digestive Diseases 1976; 21: 233

\section{Résumé}

Chez douze chiens bâtards, on a comparé l'effet sur la pression du chalédoque de morphine et de fentanyl injectés tantôt par voie intraveineuse, tantôt par voie péridurale. L'injection intraveineuse de morphine 0.1 $m g \cdot \mathrm{kg}^{-1}$ ou de fentanyl $0.01 \mathrm{mg} \cdot \mathrm{kg}^{-1}$ a augmenté de façon statistiquement significative la pression du cholédoque de $10.48 \pm 0.37$ à $21.68 \pm 0.33 \mathrm{~cm} \mathrm{H}_{2} \mathrm{O}$ pour la morphine et de $9.66 \pm 0.33$ à $14.14 \pm 0.21 \mathrm{~cm} \mathrm{H}_{2} \mathrm{O}$ pour le fentanyl. Ces augmentations de pression sont apparties de 4 à 15 minutes après l'injection pour durer de deux $a$ trois heures.

Lorsqu'une même dose de ces morphiniques a été injectée par voie péridurale, les pressions du cholèdoque sont demeurées inchangées pendant les quatre heures $q u$ a duré l'observation.

$D^{\prime}$ autres études sont prévues pour déterminer si cet effet bénéfique des morphiniques par voie péridurale se retrouve aussi en clinique humaine. 